\title{
Measuring Parental Beliefs about the Developmental Significance of Preschool Children's Daily Activities: The Children's Daily Activities-Parental Beliefs Scale
}

\author{
Konstantinos Petrogiannis ${ }^{1}$, Kalliroi Papadopoulou ${ }^{2} \&$ Despina Papoudi ${ }^{2}$ \\ ${ }^{1}$ School of Humanities, Hellenic Open University, Greece \\ ${ }^{2}$ Faculty of Early Childhood Education, National and Kapodistrian University of Athens, Greece \\ Correspondence: Konstantinos Petrogiannis, School of Humanities, Hellenic Open University, parodos \\ Aristotelous 18, Patras 26335, Greece. Tel: 30-697-728-2395. E-mail: kpetrogiannis@eap.gr
}

Received: October 9, 2012

Accepted: June 6, $2013 \quad$ Online Published: September 23, 2013

doi:10.5539/jedp.v3n2p40

URL: http://dx.doi.org/10.5539/jedp.v3n2p40

\begin{abstract}
The study presents the Children's Daily Activities-Parental Beliefs (CDA-PB) scale, a newly developed instrument providing parental assessment of the developmental significance of family-based, preschool children's daily activities. These activities are considered as primary contexts for understanding children's learning and development and parental beliefs are critical for both the organization of such activities as well as parents' participation in them. Study informants were 383 mothers of preschool children attending daycare centres and kindergartens in the greater Athens area in Greece. Mothers completed a self-report questionnaire which included the CDA-PB and two other scales targeting at the report of the frequency of daily activities' occurrence and mothers' participation in them. Following a series of principal component analysis with varimax rotation the final form of the CDA-PB scale consisted of 30 items loaded on five components representing the perceived significance for certain types of activities, namely: "Household and self-care activities", "Recurrent outings", "Pre-academic activities", "Play activities", and "Home entertainment activities". In addition, inter-correlations were revealed with the other two scales. Overall, the results are compatible with empirical evidence from different cultural settings and provide initial support for the use of this scale. Limitations of the present study and future research priorities are also addressed.
\end{abstract}

Keywords: preschool children, daily activities, scale development, maternal beliefs

\section{Introduction}

The purpose of the present paper is to describe the development of a new measure, the Children's Daily Activities-Parental Beliefs scale, which assesses the beliefs of Greek mothers about the developmental significance of family based, preschool children's daily activities. In so doing, we draw on two interrelated bodies of research: (1) the literature regarding the importance of placing child development and learning in the context of everyday activities, with special emphasis on patterns of parent-child interaction in the course of these activities and (2) the view that child participation and parent-child joint engagement in everyday activities are, to a great extent, linked with parental beliefs about their cultural and developmental significance.

The importance of daily activities to children's learning and development has been emphasized and documented in recent years under the influence of "socio-cultural" or "contextual" theories (Bronfenbrenner, 1995; Rogoff, 1990, 2003; Super \& Harkness, 1986; Vygotsky 1934/1987, 1978). In this tradition, researchers claim that child development evolves in social interaction with more able partners in the context of culturally structured environments, which comprise cultural objects and means (toys, books etc.) as well as culturally meaningful activities. The more culturally mature collaborate with the less mature in deciding the nature of the activities as well as the role of each participant (e.g., Rogoff, Mosier, Mistry, \& Göncü, 1998; Rogoff, 1990, 2003). Children and caregivers for example, continually participate in joint activities, and these activities are thought to be crucial for child development (van der Veer \& van Ijzendoorn, 1988). Through participation in culturally constructed, everyday activities under the guidance and support of others, children acquire, modify or expand the knowledge, skill and values characterizing their societies and they construct their psychological processes. Thus, everyday activities represent opportunities for children to 
participate in meaningful interaction with others, affording children experiences necessary for learning and the development of their competencies (Harkness \& Super, 2002; Lave \& Wenger, 1991; Rogoff, 2003; Vygotsky, 1978, 1934/1987).

Parents provide the earliest context for child development, through guiding children's experiences and learning in culturally appropriate everyday activities. Parents' involvement in these activities, direct (through their actual engagement) or indirect (through the types of children's activities they encourage), becomes a central component of child learning and a significant contributor to child development (Parmar, Harkness, \& Super, 2008; Rogoff, 2003). Research has demonstrated that parents guide and regulate child activities in accordance with their views about culturally appropriate developmental goals and expectations. Parental cultural values and beliefs regarding children, child development and child-rearing, have been associated with the nature of children's activities and the time spent in them (Harkness et al., 2011; Tudge et al., 1999, 2006). They also play a critical mediating role regarding parental participation and practices (Harkness \& Super, 2006; Parmar, Harkness, \& Super, 2004; Savage \& Gauvain, 1998; Suizzo, 2002, 2004; Tudge et al., 1999, 2006; Tulviste, Mizera, De Geer, \& Tryggvason, 2007), as they provide meaning to daily activities and to parent-child interactions in the context of the activities (Harkness et al., 2011; Parmar et al., 2008; Suizzo, 2002). For example, Harkness et al. (2011) demonstrated that children who spend more time in developmental or school-related activity, have parents who emphasise this activity, especially in relation to cognitive development. Also, the type, frequency and intensity of children's play have been associated with cultural beliefs about the functions of play and its significance for children and child development (Gaskins, Haight \& Lancy, 2007). Furthermore, research has shown that parents provide more support and participate in pretend play with their preschoolers, when they believe in pretend play's significance for child development (Haight et al., 1999; Rogoff et al., 1993).

The above provide the theoretical grounds for studying typically occurring, family based children's daily activities in relation to parental beliefs about the value of these activities: family based children's daily activities better represent instances which are routine and shared with parents (Harkness et al., 2011; Savage \& Gauvain, 1998) and constitute important contexts for child development, especially in the early years (Bronfenbrenner, 1995; Rogoff, 2003; Super \& Harkness, 1986). Parental beliefs about the value of everyday activities are important mediators of both the types of activities parents encourage as well as of the nature and degree of their participation in them.

This link between parental beliefs and children's daily activities has been differentially highlighted in the relevant literature. In one stream of research, parental beliefs are mostly inferred from the type of activities prevailing in a certain community or social group, rather than being studied more directly. In these studies, the emphasis is on identifying different kinds of activities which make up the context of family and community life of young children (Dunst et al., 2000; Tudge et al., 2006). The daily activities constitute major sources of learning opportumities and experiences for children, and are expected to vary as a function of cultural and/or socioeconomic background (Dunst et al., 2000; Tudge et al., 2006). In other words, daily activities are assumed to represent instantiations of values and beliefs of cultural or social groups. Tudge et al. (2006) for example, indicated that children with better educated parents were more likely to engage in activities which are assumed to prepare children for schooling, such as play with educational toys and conversations with adults.

A second way of examining the mediating role of beliefs for children's engagement in daily activities has been to identify different types of daily activities and connect them to parental values and beliefs regarding child characteristics and child-rearing. Tudge et al. (1999), for example, showed that parents who valued "self-direction" (e.g., development of self-control and sound judgment) and reported child-rearing beliefs focusing on freedom rather than discipline, had children who were more likely to be involved in and to initiate academic lessons (i.e., counting or writing), play with academic toys and conversations with adults.

A third way in which the relationship between parental beliefs and children's daily activities has been approached is through studying the beliefs parents hold regarding the meaning and significance of specific activities (Parmar et al., 2004, 2008; Savage \& Gauvain, 1998; Gauvain \& Perez, 2005). Here, the focus is on specific activities and their association with parental beliefs regarding the value of these same activities. Parmar et al. $(2004,2008)$, for example, examined parental beliefs about children's play and learning in different cultural groups, in relation to preschool children's home routines. They showed that parents' cultural background influenced their beliefs about play and learning which, in turn, were instantiated in the provision of material, in home and time organization and in actual parental participation in children's play and learning. European-American mothers, who viewed play as important for young children's cognitive and social development provided the means as well as company for play; Asian mothers on the other hand, placed more emphasis on learning activities as important for development, and thus provided more learning and less play 
opportunities. These differences were manifested even when play and learning were related to children's readiness for school (Parmar et al., 2004), an ability equally valued by both groups. Such findings denote that, linking beliefs about the value of specific activities to children's and parents' engagement with these same activities, is more informative for both direct and indirect parental influences. This is so because it takes into account the meanings of specific daily activities "from the perspective of those who organize and direct children's daily lives" (Harkness et al., 2011, p. 800). However, what appears to be lacking from these studies, is the potential to identify and portray, as fully as possible, those activities which constitute children's daily lives while, at the same time, linking them to the meanings that they have for those who organize them. Children's family based daily activities have mainly been investigated by observational work and detailed ethnographies (Tudge et al., 2000, 2006). The mediating role of parental beliefs in such activities has been studied either through observations and interviews or through questionnaires. When questionnaires have been used, they were either developed for the purposes of a specific study (thus assessing beliefs about a specific topic such as play and learning in the Parmar et al., 2004 study, for example), or they were adapted versions of existing parental beliefs scales (Tudge et al., 1999). However, existing measures of parental beliefs are relevant to children's daily activities only in a broad sense, as they tend to focus on rather general parenting attitudes, values and practices regarding child-rearing, parent-child interaction and the home environment (e.g., Fox, 1994; Holden \& Edwards, 1989; Pierce, Alfonso, \& Garison, 1998). When applied to daily activities, existing measures place their emphasis mostly on the mutual engagement of parents and children (Chantani, Prince, \& Scott, 1999) or on parental expectations about the onset of children's participation in home-based as well as in out-of-home, more formally organized activities (Savage \& Gauvain, 1998; Gauvain \& Perez, 2005). On the theoretical grounds that parental beliefs are important mediators of parental influences on children's everyday activities, it is therefore important to develop self-report instruments to assess what parents believe about these activities, as more parsimonious alternatives to interviews and observations. Such self-report instruments could provide valuable information on what parents believe their children are doing in the course of a typical day, the significance they attribute to such activities and their views concerning their participation in them. The advantage of such methods is that they may be administered to a considerable number of respondents through a survey, assessing beliefs about activities inside and outside the home and that they may also capture rarely occurring activities in a given cultural community (Chandani, Prince, \& Scott, 1999).

In this vein, the present study is an effort towards the construction and initial validation of a scale measuring parental beliefs about the significance of preschool children's family based daily activities. It relies on the argumentation about the central role of parental beliefs for both the organization of children's daily activities as well as for parental participation in such activities (e.g., Harkness \& Super, 1992, 2006; Harkness et al., 2011). Accordingly, it was assumed that parental beliefs would be associated with both the report of occurrence of these activities and, particularly, parents' participation in them.

\section{Method}

\subsection{Participants}

The initial sample consisted of 401 mothers of 201 boys and 200 girls attending daycare centres and kindergartens in middle and lower-middle class neighborhoods in the greater area of Athens, Greece. Mean ages of the mothers and children were 36 years (sd: 4.25 ) and 5 years (sd: 1.03$)$ respectively. In $58.4 \%$ of cases the target-child (i.e., the child attending the daycare centre or the kindergarten) was the only child in the families and in $61.3 \%$ were also siblings.

It should be noted herewith that it was decided to include only mothers in the sample as the principal informants for two reasons: firstly, despite the growing involvement of fathers in child rearing, mothers in Greece seem to remain the primary caregivers (Archodidou, 2010; Dragonas et al., 2005). This greater familiarity would make the task of answering the questionnaire easier for mothers ensuring, in addition, more reliable data. Secondly, research has demonstrated differences in the ways mothers and fathers are involved and interact with their children (e.g., Tudge et al., 2000).

The vast majority of the mothers were married (89\%). More than half of the mothers were higher technological college $(13.1 \%)$ or university $(39.4 \%)$ graduates. With regard to their occupational status, the majority were employees either in private business $(43 \%)$ or the civil sector $(20.4 \%)$ whereas another $18 \%$ of the respondents reported housewives. All respondents were Greek in origin and native Greek speakers. The cultural homogeneity of the sample was considered important, given the cultural sensitivity of parental beliefs.

\subsection{Procedure}

Permission was sought from the appropriate kindergarten or nursery officials to receive access to the identified 
preschool programs. Mothers were contacted via a letter explaining the purpose of the study and requesting their consent. The questionnaires were hand delivered to the selected educators and through them to the mothers that had agreed to participate. Mothers returned the completed questionnaires in a sealed envelope and the educators contacted the research team for pick-up. Return rate reached $70 \%$.

\subsection{Measures}

For the purposes of the study, the Children's Daily Activities-Parental Beliefs (CDA-PB) scale was developed aiming to reveal parents' beliefs concerning the developmental significance of children's routine daily activities. The initial version comprised 36 items that were based on the literature regarding preschool children's daily activities and parental participation (Chandani et al., 1999, 2003; Dunst, Hamby, Trivette, Raab, \& Bruder, 2000; Gauvain \& Perez, 2005; Parmar et al., 2004, 2008; Pierce et al., 1998; Tudge et al., 1999, 2000, 2006). The included items represented different types of preschool children's activities (such as play, educational, social, entertainment and work-related) evidenced both in Greek and other cultural communities' family settings. We focused on family based child daily activities, assuming that they represent characteristic instances which involve actions that are routine and shared with parents. It is in the context of such activities that opportunities for mutual engagement and participation are more commonly created (Gauvain \& Perez, 2005).

The scale was tested in a pilot study with a convenience sample of 40 mothers of preschool children that permitted for item refinement. Mothers were asked to comment on suitability, wording and content of the referred activities. 33 activities formed the final list which was used for the data analyses. The assessment of maternal views about the developmental significance of the described activities was achieved with the use of a 5-point scale ranging from "not at all important" to "extremely important".

The CDA-PB was supplemented by two other scales which adopted an identical list of activities. These measures aimed to provide evidence for two interrelated aspects: (a) the frequency of occurrence of children's activities and (b) mothers' participation in the reported daily activities. Both measures used a 5-point response scale ranging from "never" to "always" and "never" to "daily", respectively. Finally, the questionnaire included a number of questions regarding maternal and family characteristics.

\section{Results}

Following the initial data scan for cases with systematic missing values the analyses were finally carried out with 383 children for whom their mothers fully responded to all the items of the three separate scales of the questionnaire.

An initial step in the current analyses was to examine the item score distributions for univariate outliers in order to control the assumption of normality. Two of the criteria that are used for this particular screening are the level of skewness and kurtosis of the distribution. According to Hutcheson and Sofroniou (1999) the assumption of normality is satisfied if the values are within the +2 to -2 value range for skewness and +3 to -3 for kurtosis.

The analyses, that were executed for the three scales before proceeding to the examination of the construct validity of CDA-PB, showed that the assumption of normality was justified for all but one item ("Tells stories or how s/he spent the day") of the parents' participation in children's activities scale. For this particular item the distribution pattern revealed a high negative skewness and a low variance, and consequently it was excluded from any further analysis. For reasons of equivalence the corresponding items from the other two scales were also excluded giving 32 comparable items among the three scales (see Table 1). 
Table 1. Children's Daily Activities questionnaire: Item descriptive statistics and intraclass correlation coefficients

\begin{tabular}{|c|c|c|c|c|c|c|c|c|c|c|c|c|c|c|}
\hline \multirow[b]{2}{*}{ Item description } & \multicolumn{4}{|c|}{ Parental Beliefs } & \multicolumn{4}{|c|}{ Frequency of occurrence } & \multicolumn{4}{|c|}{ Mothers' participation } & \multirow[b]{2}{*}{ ICC } & \multirow[b]{2}{*}{$p$} \\
\hline & $\mathrm{M}^{(1)}$ & sd & skewness & kurtosis & $\mathrm{M}^{(2)}$ & $\mathrm{Sd}$ & skewness & kurtosis & $\mathrm{M}^{(3)}$ & sd & Skewness & kurtosis & & \\
\hline Picks up his/her things & 4,0 & 0,81 &,- 2 &,- 9 & 3,7 & 0,97 &,- 6 &, 0 & 3,9 & 0,86 &,- 7 &, 1 & .12 & $<0,001$ \\
\hline $\begin{array}{l}\text { Cleans up if s/he makes } \\
\text { a mess }\end{array}$ & 3,8 & 0,83 & 0 &,- 9 & 3,3 & 1,18 & - ,2 &,- 9 & 3,9 & 1,06 &,- 8 &, 0 & .25 & $<0,001$ \\
\hline Tidies up his/her room & 3,7 & 0,87 &,- 2 &,- 3 & 3,0 & 1,19 &,- 1 &,- 9 & 3,7 & 1,07 &,- 7 &, 0 & .23 & $<0,001$ \\
\hline Makes up his/her bed & 3,3 & 1,00 &, 1 &,- 6 & 2,0 & 1,14 & ,9 &,- 3 & 3,2 & 1,50 &,- 2 & $-1,4$ & .20 & $<0,001$ \\
\hline $\begin{array}{l}\text { Helps in tidying up the } \\
\text { house }\end{array}$ & 3,1 & 0,96 &, 3 &,- 5 & 2,7 & 1,06 &, 0 &,- 8 & 3,2 & 1,29 &,- 1 & $-1,0$ & .31 & $<0,001$ \\
\hline Helps making the table & 3,2 & 0,90 &, 3 &,- 3 & 3,2 & 1,13 &,- 3 &,- 7 & 3,5 & 1,12 &,- 4 &,- 7 & .43 & $<0,001$ \\
\hline $\begin{array}{l}\text { Prepares something } \\
\text { simple to eat }\end{array}$ & 3,3 & 0,99 &,- 1 &,- 4 & 2,3 & 1,28 &, 5 & $-1,1$ & 2,8 & 1,36 &, 1 & $-1,2$ & .40 & $<0,001$ \\
\hline Gets dressed alone & 4,1 & 0,81 &,- 5 &,- 6 & 3,6 & 1,30 &,- 6 &,- 8 & 4,3 & 0,89 & $-1,4$ & 1,7 & .35 & $<0,001$ \\
\hline Showers by him/herself & 3,6 & 1,11 &,- 4 &,- 5 & 2,1 & 1,34 & ,9 &,- 5 & 3,1 & 1,46 &,- 1 & $-1,4$ & .44 & $<0,001$ \\
\hline $\begin{array}{l}\text { Listens to the radio, } \\
\text { tape-recorder or } \mathrm{CD}\end{array}$ & 3,2 & 0,99 &, 2 &,- 6 & 3,7 & 1,13 &,- 8 &,- 1 & 3,8 & 1,05 &,- 8 &, 2 & .38 & $<0,001$ \\
\hline Watches TV & 1,8 & 0,73 & 1,1 & 2,7 & 4,3 & 1,06 & $-1,4$ & 1,2 & 3,7 & 1,08 &,- 7 &,- 3 & .31 & $<0,001$ \\
\hline Watches video or DVD & 2,0 & 0,75 & 1,0 & 2,5 & 4,1 & 0,97 & $-1,1$ & 6 & 3,4 & 1,07 &,- 4 &,- 4 & .29 & $<0,001$ \\
\hline Plays/uses the computer & 2,4 & 1,01 &, 5 &, 1 & 2,2 & 1,28 &, 7 &,- 8 & 2,5 & 1,41 &, 4 & $-1,2$ & .40 & $<0,001$ \\
\hline $\begin{array}{l}\text { Goes to the theatre or } \\
\text { cinema with an adult }\end{array}$ & 3,8 & 0,89 &,- 2 &,- 6 & 2,5 & 0,79 &,- 1 &,- 4 & 3,2 & 1,28 &, 1 & $-1,1$ & .37 & $<0,001$ \\
\hline $\begin{array}{l}\text { Goes for walks with an } \\
\text { adult }\end{array}$ & 4,1 & 0,83 &,- 7 &, 2 & 4,0 & 0,64 &,- 6 & 1,6 & 4,3 & 0,76 &,- 9 &, 4 & .32 & $<0,001$ \\
\hline $\begin{array}{l}\text { Visits friends or } \\
\text { relatives }\end{array}$ & 3,9 & 0,88 &,- 3 &,- 7 & 3,6 & 0,62 &,- 7 & 6 & 4,1 & 0,88 &,- 5 &,- 6 & .22 & $<0,001$ \\
\hline Visits friends to play & 4,1 & 0,83 &,- 5 &,- 7 & 3,1 & 0,91 &,- 4 &,- 3 & 3,5 & 1,08 &,- 2 &,- 8 & .34 & $<0,001$ \\
\hline $\begin{array}{l}\text { Goes shopping with } \\
\text { someone from the } \\
\text { family }\end{array}$ & 3,3 & 0,98 &, 0 &,- 6 & 3,6 & 0,61 & - ,6 &, 2 & 4,0 & 0,88 &,- 6 &,- 1 & .31 & $<0,001$ \\
\hline Engages in pretend play & 3,3 & 0,98 & 0 &,- 6 & 3,6 & 1,04 &,- 6 &,- 2 & 2,9 & 1,08 & 0 &,- 8 & .39 & $<0,001$ \\
\hline $\begin{array}{l}\text { Plays with other } \\
\text { children } \varepsilon \kappa \tau o ́ \varsigma ~ \sigma \chi 0 \lambda \varepsilon i ́ o v\end{array}$ & 4,4 & 0,79 &,- 9 &,- 4 & 3,7 & 0,88 &,- 4 &,- 1 & 2,7 & 1,05 &, 1 &,- 8 & .17 & $<0,001$ \\
\hline Plays with puzzle & 3,9 & 0,90 &,- 3 &,- 6 & 3,5 & 0,95 &,- 5 &, 0 & 3,4 & 0,96 &,- 4 &,- 2 & .40 & $<0,001$ \\
\hline $\begin{array}{l}\text { Plays with constructive } \\
\text { toys }\end{array}$ & 3,8 & 0,94 &,- 3 &,- 8 & 3,6 & 1,07 & - ,6 &,- 2 & 3,2 & 1,09 &,- 4 &,- 6 & .40 & $<0,001$ \\
\hline Plays outside & 4,3 & 0,75 &,- 7 &,- 7 & 3,8 & 0,69 &,- 3 &, 0 & 3,7 & 0,97 &,- 4 &,- 3 & .18 & $<0,001$ \\
\hline $\begin{array}{l}\text { Plays with educational } \\
\text { toys }\end{array}$ & 4,3 & 0,78 &,- 9 &, 0 & 3,9 & 0,78 &,- 7 & 1,1 & 3,8 & 0,93 &,- 6 &, 2 & .40 & $<0,001$ \\
\hline $\begin{array}{l}\text { Plays with toy cars, } \\
\text { dolls or other toys }\end{array}$ & 3,5 & 0,97 & 0 &,- 7 & 4,5 & 0,74 & $-1,5$ & 2,6 & 3,1 & 1,04 &,- 2 &,- 8 & .24 & $<0,001$ \\
\hline Plays with board games & 3,9 & 0,90 &,- 2 &,- 8 & 3,1 & 1,17 &,- 4 &,- 7 & 3,1 & 1,17 &,- 2 &,- 7 & .45 & $<0,001$ \\
\hline $\begin{array}{l}\text { Turns pages on books } \\
\text { with pictures }\end{array}$ & 4,2 & 0,78 &,- 6 &,- 5 & 4,3 & 0,82 & $-1,1$ & 1,1 & 4,0 & 0,84 &,- 7 &, 4 & .30 & $<0,001$ \\
\hline Pretends to read books & 3,9 & 0,91 &,- 4 &,- 8 & 4,0 & 1,01 & $-1,1$ &, 8 & 4,3 & 0,74 &,- 8 & 6 & .27 & $<0,001$ \\
\hline Tries to write & 4,4 & 0,78 &,- 9 &,- 2 & 4,1 & 1,02 & $-1,2$ & ,9 & 3,8 & 1,04 &,- 9 &, 3 & .34 & $<0,001$ \\
\hline Draws & 4,3 & 0,77 &,- 8 &,- 5 & 4,6 & 0,64 & $-1,9$ & 3,6 & 3,6 & 0,96 &,- 6 &, 0 & .16 & $<0,001$ \\
\hline $\begin{array}{l}\text { Pretends to read at } \\
\text { bedtime }\end{array}$ & 3,4 & 1,11 &, 0 & $-1,0$ & 3,0 & 1,46 &, 0 & $-1,4$ & 3,6 & 1,32 &,- 6 &,- 8 & .44 & $<0,001$ \\
\hline $\begin{array}{l}\text { Tells stories or how s/he } \\
\text { spent the day }\end{array}$ & 4,3 & 0,79 &,- 8 &,- 7 & 4,1 & 1,09 & $-1,0$ &, 1 & 4,8 & 0,58 & $-3,7$ & 16,7 & n.a. & \\
\hline Sings & 3,8 & 1,02 &,- 4 &,- 8 & 4,2 & 0,98 & $-1,3$ & 1,3 & 4,1 & 1,03 & $-1,0$ &, 3 & .29 & $<0,001$ \\
\hline
\end{tabular}

${ }^{(1)}$ Range: " $1=$ not important" to " $5=$ extremely important"; ${ }^{(2)}$ Range: " $1=$ never" to " $5=$ every day/daily"; ${ }^{(3)}$ Range: " $1=$ never" to " $5=$ always" 


\subsection{Factor Analysis of $C D A-P B$}

In order to examine the latent structures that may reflect mothers' beliefs about the developmental significance of family-based preschool children's daily activities, a series of exploratory factor analyses were performed with the 32 items of this particular scale. As a first step the internal consistency of the scale was examined. One of the criteria adopted for refining the items was the item-total coefficient (correlations of each item with the sum of the remaining items). A low coefficient indicates that the item does not fit with the rest of the items that make up the scale. Usually, items having item-total coefficients of less than .3 also have very poor variance of responses. This value is considered as a minimum acceptable limit for an item inclusion for further scale analyses since it is an indication that there is little variance with the total scale score (Field, 2005).

With regard to the corrected item-total coefficients for each of the 32 items, all but three item-total correlations ranged from .4 to .65. These three items ("Watches TV", "Watches video or DVD", "Plays/ uses the computer") were at the borderline regarding the item-total correlation value (.3). However, due to the sufficient sample size for scale analysis (Kim \& Mueller, 1978) it was decided to retain these items for the rest of the analyses. No item had negative item-total correlation.

The decision was further supported following an additional alpha coefficient computation for the total scale if every item is deleted. This result represents the values of the overall alpha if a particular item isn't included in the calculation, i.e., they reflect the change in Cronbach's alpha that would be seen if a particular item was deleted (Field, 2005). The analyses revealed that none of the items substantially affected reliability if they were deleted. The overall alpha coefficient (Cronbach, 1951) for the final scale was .915.

An additional screening was performed before proceeding to the factor analyses, in order to control for every possible assumption that should be met for this option given that it was one of the aims of the current study. Since one of the basic assumptions for the factor analyses is the sample size, initially a sufficient number of participants was ensured. Based on the relevant literature, recommendations for item-to-response ratios range from 1:4 (Rummel, 1970) to at least 1:10 (Schwab, 1980) for each set of scales to be factor analyzed. Gorsuch (1983) suggested that there should be 5 participants per variable and the sample size should be at least 200. Accordingly, Streiner (1994) suggested that there should be 5 individuals for every variable if the sample consists of more than 100 participants and 10 individuals for each variable for a smaller sample size. Other experts, however, suggest that in most cases, a sample size of 150 observations is required to obtain an accurate solution in exploratory factor analysis as long as item intercorrelations are reasonably strong (Guadagnoli \& Velicer, 1988).

The final number of 383 participants with a complete dataset was considered large enough to produce a reliable solution when a factor analytic procedure is employed (Kim \& Mueller, 1978). This was further confirmed by the use of another criterion to assess the appropriateness for factor analysis, the Kaiser-Meyer-Olkin measure (KMO test) of sampling adequacy. The overall measure of sampling adequacy (MSA) for the scale was highly acceptable (.89) and well above the recommended value of .5 (Kaiser, 1970).

Several well-recognized criteria for the factorability of the correlation were used. Firstly, the factorability of the 32 items was examined through the inter-relationships among the items. All of the 32 items were correlated with at least one other item, suggesting reasonable factorability through the bivariate correlations.

According to Dziuban and Shirkey (1974), another measure for assessing item intercorrelation for acceptability before applying factor analysis is Bartlett's (1950) test of sphericity. If the scale items are uncorrelated, attempting a factor analysis would be of questionable value. Bartlett's test of sphericity for the scale item correlation matrix was significant $\left(x^{2}{ }_{(496)}=6400.28, p<.001\right)$. Although this test is sensitive to sample size, the finding is more than adequate as a criterion for proceeding with the factor analysis.

Furthermore, an anti-image matrix (R-matrix) of covariances and correlations was calculated. All elements on the diagonal of this matrix were greater than .5, supporting the inclusion of each item in the factor analysis (Field, 2005). In addition, the variables were not highly correlated since the relevant screening for any multicollinearity effect through the Determinant $(=0.0000000284)$ in R-matrix did not extract a value greater than 0.00001 (Field, 2005).

\subsection{The Structural Components of the Scale}

Exploratory factor analysis (EFA) is generally used to discover the factor structure of a measure and to examine its internal reliability. EFA is often recommended when researchers have no hypotheses about the nature of the underlying factor structure of their measure.

The data met the conditions for exploratory factor analysis to identify a viable factor structure: the study was 
purpose-designed for exploratory factor analysis, the variables were intuitively related, the data set was factorable, the sample size was sufficient (Comrey \& Lee, 1992), and sampling statistics were acceptable.

The dimensionality of the 32 items of the scale was examined through principal-components analysis (PCA). The exploratory technique of PCA is one of the most common methods used by data analysts to provide a condensed description and describe patterns of variation in multivariate data sets. Moreover, PCA is also able to retain meaningful information in the early axes whereas variation associated with experimental error, measurement inaccuracy, and/or rounding is summarized in later axes (Gauch, 1982). A major advantage of this method is that it is not based on any distributional assumptions although in this study the assumptions of normality were met.

The procedures were combined with orthogonal (varimax) and oblique (promax) rotations, with Kaiser normalization. Both solutions were used because "using orthogonal rotation results in a loss of valuable information if the factors are correlated, and oblique rotation should theoretically render a more accurate, and perhaps more reproducible, solution. If the factors are truly uncorrelated, orthogonal and oblique rotation produce nearly identical results (Costello \& Osborne, 2005, p. 3).

To guarantee the explanatory power of the factors the principle criteria for evaluating the factor solutions were (i) meaningfulness and interpretability (factors that made sense and were consistent with the literature), (ii) scientific usefulness, (iii) parsimony, and (iv) fewer than 5\% non-redundant residuals. Factor adequacy was the most important criterion for determining the appropriate number of factors and, therefore, for evaluating parsimony. It was assessed on theoretical considerations and factor stability: factors with at least three items, primary item loadings .40 , and factor and item structures common to several solutions.

In addition, the factors should have an eigenvalue from the reduced correlation matrix larger than unity, applying the Kaiser-Guttman criterion which ensures that the last retained factor explains a higher proportion of the total variance than an "average" variable. Solutions based on this criterion proved to be consistent with Cattell's "scree" criterion (Cattell, 1966) which was also used (Kline, 1993). Deviation from this is only allowed if the interpretability of the factors is at issue.

Furthermore, in determining the best factor solution, attention was paid to the percentage of the variance explained. With respect to the communality values for the items, items loading lower than .15 would be removed in principle. However, there was no such finding. Factor analyses were repeated until all the items included in the analysis met all criteria.

Preliminary EFAs, using the approaches described above, indicated the extraction of 7 factors not achieving consistency with the criterion of parsimony. Hence the analysis was set to produce 6 and 5 factors using the same approaches. The higher structure stability producing meaningful, interpretable, and scientifically useful factors was the 5-factor solution using PCA with varimax rotation. At this stage two items were removed ("Listens to the radio, tape-recorder or CD", "Engages in pretend play") since they consistently presented a mixed picture regarding their loadings among the factors, giving a final scale of 30 items that were organized under five factors. This factor solution was further confirmed by using the Monte Carlo PCA for Parallel Analysis computer program (Watkins, 2000) with 200 replications to provide stable eigenvalue estimates.

Stevens (1996) recommended interpreting only factor loadings with an absolute value greater than .4. In the present analysis all the items fulfilled this minimum loading criterion as well as the more conservative criterion of Tabachnick and Fidell (2001) who cite .32 as a good rule of thumb for the minimum loading of an item. With regard to the final five components solution, Kaizer's criterion seems to be accurate since the sample size exceeds 250 and the average communality after extraction is .6 (Field, 2005).

Item communalities $\left(h^{2}\right)$, which are a measure of variance explained by the extracted factors, were sufficiently high, with several adequate to strong loaders (>.5) and a restricted number of "crossloading" items, and finally no factor had less than three items.

The individual items retained in the model and factor loadings are presented in Table 2, together with the communalities $\left(h^{2}\right)$ as well as their eigenvalues and the percentage of variance explained. The internal consistency using Cronbach's (1951) coefficient for each factor is also displayed. 
Table 2. Principal Component Analysis (varimax rotation) of the CDA-PB scale: Item loadings and communalities

\begin{tabular}{|c|c|c|c|c|c|c|}
\hline \multirow[b]{2}{*}{ Item } & \multicolumn{5}{|c|}{ Components } & \multirow[b]{2}{*}{$h^{2}$} \\
\hline & $I$ & II & III & $I V$ & $V$ & \\
\hline Tidies up his/her room & .84 & & & & & 0.73 \\
\hline Makes up his/her bed & .80 & & & & & 0.66 \\
\hline Cleans up if s/he makes a mess & .79 & & & & & 0.67 \\
\hline Helps in tidying up the house & .75 & & & & & 0.61 \\
\hline Picks up his/her things & .72 & & & & & 0.61 \\
\hline Helps making the table & .71 & & & & & 0.57 \\
\hline Prepares something simple to eat & .64 & & & & & 0.50 \\
\hline Gets dressed alone & .59 & & & & & 0.51 \\
\hline Showers by him/herself & .56 & & & & & 0.54 \\
\hline Visits friends or relatives & & .84 & & & & 0.73 \\
\hline Goes for walks with an adult & & .83 & & & & 0.73 \\
\hline Visits friends to play & & .83 & & & & 0.71 \\
\hline $\begin{array}{l}\text { Goes to the theatre or cinema with } \\
\text { an adult }\end{array}$ & & .74 & & & & 0.56 \\
\hline Plays outside & & .62 & & & & 0.58 \\
\hline Plays with other children & & .58 & & & & 0.39 \\
\hline $\begin{array}{l}\text { Goes shopping with someone from } \\
\text { the family }\end{array}$ & & .54 & & & & 0.43 \\
\hline Pretends to read books & & & .76 & & & 0.64 \\
\hline Tries to write & & & .69 & & & 0.53 \\
\hline Pretends to read at bedtime & & & .64 & & & 0.48 \\
\hline Draws & & & .63 & & & 0.57 \\
\hline Turns pages on books with pictures & & & .60 & & & 0.63 \\
\hline Sings & & & .51 & & & 0.45 \\
\hline Plays with educational toys & & & .42 & & & 0.46 \\
\hline Plays with puzzle & & & & .76 & & 0.67 \\
\hline Plays with constructive toys & & & & .75 & & 0.69 \\
\hline Plays with board games & & & & .65 & & 0.69 \\
\hline $\begin{array}{l}\text { Plays with toy cars, dolls or other } \\
\text { toys }\end{array}$ & & & & .57 & & 0.53 \\
\hline Watches video or DVD & & & & & .86 & 0.78 \\
\hline Watches TV & & & & & .85 & 0.75 \\
\hline Plays/uses the computer & & & & & .56 & 0.47 \\
\hline Eigenvalues & 8.60 & 3.78 & 2.12 & 1.83 & 1.52 & \\
\hline$\%$ of variance, post-rotationally & 16.48 & 15.04 & 11.55 & 9.83 & 6.59 & \\
\hline Cronbach alpha & .88 & .87 & .83 & .84 & .7 & \\
\hline
\end{tabular}

Note. For presentation purposes the items were re-ordered and sorted by item-loadings.

Components: I: Household and self-care activities, II: Recurrent outings, III: Pre-academic activities, IV: Play activities, V: Home entertainment 
The analysis revealed a strong first factor with 9 items accounting for $16.48 \%$ of the variance (post-rotationally) whereas all five factors together accounted for $59.49 \%$ of the total variance. This factor seems to reflect the importance that mothers give to "household and self-care activities", including items such as "Picks up his things", "Cleans up his/her room if s/he makes a mess", "Tidies up his/her room", "Gets dressed alone".

Seven items entered the second factor accounting for the second largest post-rotation variance (15.04\%). Items like "Goes to the theatre or cinema with an adult", "Goes out for walks with an adult", "Visits friends to play" may be considered as "recurrent outings" related to the child's out of home entertainment and sociability.

The third factor (accounting for $11.55 \%$ of the variance) includes maternal views about the importance of educationally oriented and learning activities, mostly related to forthcoming school tasks ("pre-academic activities"). "Pretends to read books", "Tries to write", and "Draws" are typical items of this factor.

The final two factors have an orientation to "play" and "home entertainment" respectively. Hence, the fourth factor is composed of four items which are related to play with more traditional or conventional toys/games (e.g., "Plays with puzzle", "Plays with toy cars, dolls or other toys"). The fifth factor is made up of three items that refer to technology and media use ("Watches TV", "Watches video or DVD", "Plays/uses the computer") mainly for entertainment.

\subsection{The Relatedness of Maternal Beliefs of Children's Daily Activities with Occurrence and Maternal Participation}

A central assumption of the study was that Children's Daily Activities-Parental Beliefs scale representing mothers' assessment of the importance of each of the listed activities would be linked both with the way mothers observe children's activities and their participation in these activities with their children (both in terms of frequency of occurrence).

For the examination of this hypothesis a two stage procedure was followed. Firstly, the item-by-item correlations among CDA-PB and the other two scales would allow a screening of potential consensus between mothers' responses. For this reason the intraclass correlation coefficient (ICC) (Shrout \& Fleiss, 1979) procedure was applied. As shown in Table 1 the coefficients indicated a "fair" but statistically significant agreement with only four items presenting a lower than .2 IC coefficient (McGraw \& Wong, 1996). The findings suggest that although the index is close to moderate there is a statistically significant consensus in mothers' responses through the three scales and more specifically, the more important a mother considers an activity the more frequently this activity is reported by her and the more frequently she seems to get personally involved in this activity.

In a second stage, following the factorial solution, five composite variables were computed for the CDA-PB scale based on the mean scores of the constituent items for each component. Accordingly, the same procedure was applied for the other two scales producing five new scores in each scale which represented the average frequency of occurrence of the listed children's daily activities and mothers' participation to them accordingly. Table 3 presents the correlation pattern among all the composites variables. As expected all the inter-correlations were statistically significant confirming the congruence between beliefs, reported occurrence and mothers' participation in children's daily activities. 
Table 3. Correlation matrix of the composite variables of the three scales regarding children's daily activities

\begin{tabular}{|c|c|c|c|c|c|c|c|c|c|c|}
\hline & 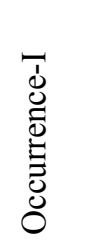 & 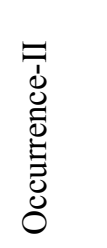 & 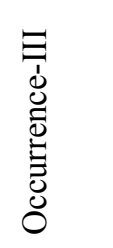 & 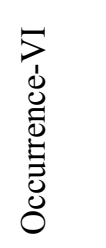 & 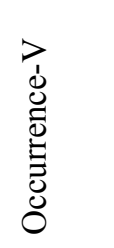 & 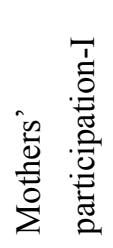 & 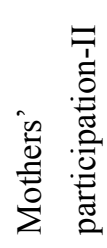 & 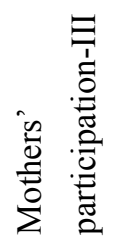 & 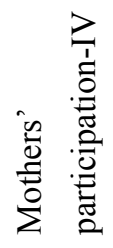 & 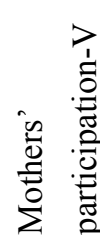 \\
\hline CDA-BP-I & $.251^{* *}$ & & & & & $.191^{* *}$ & & & & \\
\hline CDA-BP-II & & $.300^{* *}$ & & & & & $.262^{* *}$ & & & \\
\hline CDA-BP-III & & & $.312^{* *}$ & & & & & $.324^{* *}$ & & \\
\hline CDA-BP-IV & & & & $.361^{* *}$ & & & & & $.366^{* *}$ & \\
\hline CDA-BP-V & & & & & $.322^{* *}$ & & & & & $.360^{* *}$ \\
\hline $\begin{array}{r}\text { Mothers' } \\
\text { participation-I }\end{array}$ & $.507^{* *}$ & & & & & & & & & \\
\hline $\begin{array}{c}\text { Mothers' } \\
\text { participation-II }\end{array}$ & & $.579^{* *}$ & & & & & & & & \\
\hline $\begin{array}{r}\text { Mothers' } \\
\text { participation-III }\end{array}$ & & & $.510^{* *}$ & & & & & & & \\
\hline $\begin{array}{l}\text { Mothers' } \\
\text { participation-IV }\end{array}$ & & & & $.581^{* *}$ & & & & & & \\
\hline $\begin{array}{r}\text { Mothers' } \\
\text { participation-V }\end{array}$ & & & & & $.401^{* *}$ & & & & & \\
\hline
\end{tabular}

Components: I: Household and self-care activities, II: Recurrent outings, III: Pre-academic activities, IV: Play activities, V: Home entertainment

\section{Discussion}

In this paper, we have outlined the development and initial validation of the CDA-PB, an instrument for the measurement of maternal beliefs about the developmental significance of preschool children's daily activities. This effort contributes to existing research by introducing an easy and parsimonious way of studying this topic which has been highly linked to the understanding of child development in recent sociocultural approaches (e.g., Harkness \& Super, 2006; Rogoff, 1990, 2003).

The scale was simple to administer and well accepted by mothers. Its internal consistency was satisfactory. Item appropriateness was secured by including types of activities evidenced in cross-cultural studies and research on children's home environment and activities (e.g., Chandani et al., 1999; Parmar et al., 2004, 2008; Pierce et al., 1998; Tudge et al., 1999, 2000, 2006). Its cultural appropriateness was established through checking for clarity and relevance with mothers of young children.

The structural analysis of the mothers' beliefs in the importance of children's daily activities showed that the scale is a parsimonious and robust measure on the basis of its strong overall consistency as well as the specific components' internal consistency, although neither of the related subscales were as strong as the overall measure.

A distinct five-factor solution was extracted from the principal components analysis, namely "Household and self-care activities", "Recurrent outings", "Pre-academic activities", "Play" and "Home entertainment". The first two factors were the most influential explaining in almost equal proportion the biggest part $(31,5 \%)$ of the total variance $(59,5 \%)$ explained post-rotationally by the five variables that constitute the scale.

These factors are similar to categories of preschool children's activities demonstrated by earlier qualitative (e.g., Parmar et al., 2004, 2008; Tudge et al., 1999, 2000, 2006; Chandani, Scott, \& Prince, 2003) and quantitative (Chandani et al., 1999) research in different cultures. They represent a mix of activities acquainting the child 
with daily chores, activities enabling the child to acquire independence and social competence, activities providing the child with opportunities to practice developing skills and to gain new competences and activities providing broader cultural opportunities to express interest and to gain pleasure. Such activities are assumed to constitute the context of diverse cultural learning opportunities for children in their daily living which become the source of child development (Dunst et al., 2000; Göncü, 1999; Rogoff, 2003; Rogoff et al., 1993). They also relate to dimensions of mothers' developmental goals (e.g., Pierce et al., 1998; Rosenthal \& Roer-Strier, 2001), such as autonomy, responsibility, sociability and educational development. More specifically, the first factor indicates the significance that mothers give to children's participation in "household chores" as well as to behaviours (such as self-care) that contribute to the gaining of autonomy/independence. The items included under this factor are similar to what Tudge et al. (2006) describe as "work activities" as well as to Parmar's et al. $(2004,2008)$ "household chores". Further to this, the included items point to the dimension of "autonomy", in a way similar to the respective categories in Rosenthal and Roer-Strier's (2001) research and the Pierce et al. (1998) questionnaire. It appears to be a category that reflects an emphasis on cultivating a sense of responsibility alongside autonomy and independence. In fact, previous research has variably interpreted this emphasis in terms of family cohesion and interdependence (e.g., Delgado-Gaitan, 1994; Taylor, 1994; Vega, Hough, \& Romero, 1983) as well as in terms of valuing independent planning of socially responsible behaviours (e.g., Stevenson \& Stigler, 1992). With great caution at this stage of research it could be argued that in this case, the factor of "household and self care activities" may reflect an emphasis of Greek mothers on values such as respect and responsibility; a similar finding has been evidenced by previous research with Greek families (Tamis-Lemonda et al., 2002). However, the above values also appear to be intertwined with a tendency towards independence, which also appears to be characteristic of contemporary Greek society (Georgas, 2000; Keller et al., 2006; Tamis-Lemonda et al., 2002).

In a similar way the second factor, referring to children's "recurrent outings", appears to reflect mothers' emphasis on activities that encourage social interaction with family and friends as well as participation in activities with societal context, typical in urbanized environments. Such activities ensure the child's social competence with respect to forming relations with others as well as to becoming a competent member of its social group. This type of activities has also been evidenced in previous, mostly qualitative, research on the everyday life of young children and the activities they engage in (Dunst et al., 2000; Tudge et al., 2006).

The remaining factors, namely "pre academic activities", "play" and "home entertainment", also represent activities evidenced by previous research in different cultures (e.g., Parmar et al., 2008; Tudge et al., 1999, 2000, 2006) with different meanings among different cultural groups (Harkness et al., 2011). The factor analysis of the present study indicates that Greek mothers also differentiate between playful activities such as pretending to read or write and behaviours being more clearly characterized as play, such as play with toys. At the same time however, both these categories appear to involve items with an educational orientation. This emphasis on the importance of providing children with educational learning opportunities (even in their play), has been evidenced in Greek society both in the family as well as in the pre-school and mostly the school context (Kontogiannopoulou-Polydoridi, 2003; Tsoukalas, 1977). It may be also related with the characteristics of the present study's sample, that is fairly well educated parents with children attending day-care and pre-school centers. Research has shown that both these factors are associated with encouragement of school-relevant activities, which also characterize children's play (e.g., educational toys, toys that promote attainment of school-relevant skills) (e.g., Tudge et al., 2006). Further analyses would demonstrate the respective importance of these factors for child development as perceived by mothers.

Two more scales including the same items were developed in order to examine the level of correspondence between mothers' beliefs concerning the importance of children's daily activities and frequency ratings for children's engagement as well as mothers' participation in these activities. Although in similar questionnaires -used, however, in different cultural contexts and for other purposes (e.g., Mowder, Harvey, Pedro, Rossen, \& Moy, 1993; Mowder \& Sanders, 2008)- this kind of relationship has been investigated, the three scales were examined due to heuristic considerations analogous to those expressed by other researchers (e.g., Mowder \& Sanders, 2008) such as that respondents could indicate parental belief or behavioral anchor importance, but not engage in the activity. In addition, it was a matter of research interest whether such a connection could be supported in other cultural settings such as urban areas of Athens, Greece. If such a connection could be revealed this would be sufficient evidence to proceed solely to further examination of the part of the questionnaire that refers to parental beliefs. This attempt would also support the relevant literature on what other studies from the field of cultural developmental psychology have indicated concerning the role of parental beliefs as a guide to parents' decisions on childrearing (Harkness \& Super, 2006; Rogoff, 2003; Tudge et al., 1999). 
Thus, with regard to correspondence between maternal beliefs with the other two scales, i.e., report of occurrence of children's involvement in daily activities and maternal engagement in them, initial analysis of the data provided indications about the expected regulatory function of maternal beliefs. The examination of the item-by-item correlations indicated a fair and statistically significant agreement. The intraclass correlation coefficients were ranged at a satisfactory level, a finding that could be considered as an indication of construct validity. In addition, the intercorrelations between the composite factor scores of CDA-PB with the equivalent composite scores of the other two scales confirmed the evidence through the statistically significant correlation coefficients. These findings suggest that the more important a mother considers a daily activity the more frequently this activity is perceived to appear in her child's repertoire and the more frequently she seems to participate in this activity herself. In other words, the perceived developmental significance of specific daily activities seems to underlie what mothers say about the daily activities of their children and about their engagement in children's activities.

At the same time, a number of limitations should be considered. First, the study focused only on Greek mothers and, although the emergent categories of activities have been evidenced in different cultural groups by previous research, the specific meanings of the activities and their cultural similarities and differences must be established in studies with diverse cultural and social groups. In addition, further research comparing the current scale with other established measures on parental perceptions about the parental role and child rearing practices as well as parental values, expectations and beliefs regarding child development might enhance its validity by determining the instrument's similarities and areas of distinctiveness. The validity of the instrument could be further established through small scale observational data and interviews with mothers on the same issues. Finally, additional research on the variation of maternal participation in relation to mothers' socio-demographic and psychological characteristics and other contextual features may refine the current parenting measure. The relevant research will only confirm if CDA-PB scale will be proved a significant aid for the assessment of parental beliefs in studies concerning children's daily activities and those regarding parent-child joint engagement in these activities.

Overall, the findings of this study support the CDA-PB scale as an easy to use, acceptable and fairly well constructed measure of parental beliefs about the developmental significance of preschoolers' daily activities. The development of such a scale contributes to existing measures of parental beliefs by providing a research tool that can be applied to a wide variety of investigations related to the daily activities of children and to parents' engagement in them. Using such an instrument may ultimately assist researchers to have a clearer view with regard to parents' engagement in children's everyday lives, a powerful context for the development of their children. Furthermore, this scale could be used with different cultural and social groups either in Greece or abroad to investigate similarities and differences in parents' beliefs and engagement in childrens' daily activities. It could be also used as a basic tool in order to implement preventive interventions that aim to promote parent-child joint activities.

\section{References}

Archodidou, D. (2010). The position and the role of the "new father". Unpublished PhD Thesis, University of Athens.

Bartlett, M. S. (1950). Tests of significance in factor analysis. British Journal of Psychology, Statistical Section, 3, 77-85. http://dx.doi.org/10.1111/j.2044-8317.1950.tb00285.x

Bronfenbrenner, U. (1995). Developmental ecology through space and time: A future perspective. In P. Moen, G. H. J. Elder, \& K. Luscher (Eds.), Examining lives in context: Perspectives on the ecology of human development (pp. 619-647). Washington, DC: American Psychological Association.

Cattell, R. B. (1966). The scree test for the number of factors. Multivariate Behavioural Research, 1, 140-161. http://dx.doi.org/10.1207/s15327906mbr0102_10

Chandani, K., Scott, S., \& Prince, MJ. (2003). Time budgets of the mothers of pre-school children: An analysis of mother-child joint activities. British Journal of Developmental Psychology, 21, 273-283.

Chandani, K., Prince, M. J., \& Scott, S. (1999). Development and initial validation of the Parent-Child Joint Activity Scale: a measure of joint engagement in activities between parent and pre-school child. International Journal of Methods in Psychiatric Research, 8(4), 219-229. http://dx.doi.org/10.1002/mpr.73

Comrey, A. L., \& Lee, H. B. (1992). A first course in factor analysis. Hillsdale, NJ: Lawrence Erlbaum Associates.

Costello, A. B., \& Osborne, J. (2005). Best practices in exploratory factor analysis: Four recommendations for 
getting the most from your analysis. Practical Assessment, Research and Evaluation, 10(7), 1-9.

Cronbach, L. J. (1951). Coefficient alpha and the internal structure of tests. Psychometrika, 16, 297-334. http://dx.doi.org/10.1007/BF02310555

Delgado-Gaitan, C. (1994). Socializing young children in Mexican-American families: An intergenerational perspective. In P. M. Greentield, \& R. R. Cocking (Eds.), Cross-cultural roots of minority child development (pp. 55-86). Hillsdale, NJ: Erlbaum.

Dragonas, Th., Dimitrakaki, C., Zaharaki, L., Roberts, R., Ispanovic-Radojkovic, V., Rudic, N., Radojkovich, A., Ozsivadjian, A., Vizacou, S., Paradisioti, A., Turunen, M., Puura, K., \& Mantymaa, M. (2005). The sociocultural context of the European Early Promotion Project. The International Journal of Mental Health Promotion, 7(1), 32-40. http://dx.doi.org/10.1080/14623730.2005.9721948

Dunst, C. J., Hamby, D., Trivette, C. M., Raab, M., \& Bruder, M. B. (2000). Everyday family and community life and children's naturally occurring learning opportunities. Journal of Early Intervention, 23(3), 151-164. http://dx.doi.org/10.1177/10538151000230030501

Dziuban, C. D., \& Shirkey, E. C. (1974). On the psychometric assessment of correlation matrices. American Educational Research Journal, 11, 211-216.

Field, A. (2005). Discovering statistics using SPSS. Beverly Hills, CA: Sage.

Fox, R. A. (1994). Parent behavior checklist. Branton, VT: Clinical Psychology Publishing Company.

Gaskins, S., Haight, W., \& Lancy, D. F. (2007). The cultural construction of play. In A. Göncü, \& S. Gaskins (Eds), Play and development: Evolutionary, sociocultural and functional perspectives (pp. 179-202). Mahuah, NJ.: Laurence Earlbaum.

Gauch, H. G. (1982). Multivariate analysis in community ecology. Cambridge: Cambridge University Press. http://dx.doi.org/10.1017/CBO9780511623332

Gauvain, M., \& Perez, S. (2005). Parent-child participation in planning children's activities outside of school in European American and Latino families. Child Development, 76(2), 371-383. http://dx.doi.org/10.1111/j.1467-8624.2005.00851_a.x

Georgas, D. (2000). The psychodynamics of the Greek family: Similarities and differences with other countries. In A. Kalantzi-Azizi, \& I. Bezevegis (Eds), Issues in continuing education/ sensitisation of mental health professionals for children and adolescents. Athens: Ellinika Grammata [in Greek].

Göncü, A. (1999). Children's engagement in the world: Sociocultural perspectives. Cambridge: Cambridge University Press.

Gorsuch, R. L. (1983). Factor analysis. Hillsdale, NJ: Lawrence Erlbaum.

Guadagnoli, E., \& Velicer, W. F. (1988). Relation of sample size to the stability of component pattems. Psychological Bulletin, 103, 265-275. http://dx.doi.org/10.1037/0033-2909.103.2.265

Haight, W., Wang, X. L., Fung, H., Williams, K., \& Mintz, J. (1999). Universal, developmental and variable aspects of young children's play: A cross-cultural comparison of pretending at home. Child Development, 70(6), 1477-1488.

Harkness, S., \& Super, C. (1992). Parental ethnotheories in action. In I. E. Sigel, A.V. McGillicuddy-DeLisi, \& J. Goodnow (Eds.), Parental belief systems: The psychological consequences for children (pp. 373-392). Hillsdale, NJ: Lawrence Erlbaum.

Harkness, S., \& Super, C. (2002). Culture and parenting. In M. Bornstein (Ed.), Handbook of parenting (Vol 2. Biology and ecology of parenting, pp. 253-280). Mahwah, NJ: Lawrence Erlbaum.

Harkness, S., \& Super, C. (2006). Themes and variations: Parental ethnotheories in Western cultures. In K. Rubin, $\&$ O. Chang (Eds.), Parenting beliefs, behaviors and parent-child relations: A cross-cultural perspective (pp. 61-80). London: Psychology Press.

Harkness, S., Zylicz, P. O., Super, C., Welles-Nystrom, B., Bermudez, M. R., Bonichini, S., Moscardino, U., \& Mavridis, C. (2011). Children's activities and their meanings for parents: a mixed-methods study in six western cultures. Journal of Family Psychology, 25(6), 799-813.

Holden, G., \& Edwards, L. (1989). Parental attitudes toward child rearing: Instruments, issues, and implications. Psychological Bulletin, 106, 29-58. http://dx.doi.org/10.1037/0033-2909.106.1.29 
Hutcheson, G., \& Sofroniou, N. (1999). The multivariate social scientist. Thousand Oaks, CA: Sage.

Kaiser, H. F. (1970). A second-generation Little Jiffy. Psychometrica, 35, 401-415. http://dx.doi.org/10.1007/BF02291817

Keller, H., Lamm, B., Abels, M., Yovsi, R., Borke, J., Jensen, H., Papaligoura, Z., Holub, C., Lo, W., Tomiyama, A. J., Su, Y., Wang, Y., \& Chaudhary, M. (2006). Cultural models, socialization goals, and parenting $\begin{array}{lllll}\text { ethnotheories. Journal of Cross-Cultural Psychology, 37(2), 155-172. } & \text { of }\end{array}$ http://dx.doi.org/10.1177/0022022105284494

Kim, J. O., \& Mueller C. W. (1978). Factor analysis: Statistical methods and practical issues. Beverly Hills: Sage.

Kline, P. (1993). The handbook of psychological testing. London: Routledge.

Kontogiannopoulou-Polydoridi, G. (2003). Educational policy and practice: Sociological analysis. Athens: Ellinika Grammata. [in Greek]

Lave, J., \& Wenger, E. (1991). Situated Learning: Legitimate Peripheral Participation. N.Y.: Cambridge University Press.

McGraw, K. O., \& Wong, S. P. (1996). Forming inferences about some intraclass correlation coefficients. Psychological Methods, 1(1), 30-46 (Correction, Vol. 1, No. 4, 390). http://dx.doi.org/10.1037//1082-989X.1.1.30

Mowder, B. A., Harvey, V. S., Pedro, M., Rossen, R., \& Moy, L. (1993). Parent role questionnaire: Psychometric $\begin{array}{lllll}\text { qualitiess. Psychology in the Schools, 30(3), } & \text { 211. }\end{array}$ http://dx.doi.org/10.1002/1520-6807(199307)30:3<205::AID-PITS2310300302>3.0.CO;2-Q

Mowder, B. A., \& Sanders, M. (2008). Parent behavior importance and parent behavior frequency questionnaires: Psychometric characteristics. Journal of Child and Family Studies, 17(5), 675-688.

Parmar, P., Harkness, S., \& Super, C. M. (2004). Asian and Euro-American parents' ethnotheories of play and learning: Effects on preschool children's home routines and school behaviour. International Journal of Behavioral Development, 28(2), 97-104. http://dx.doi.org/10.1080/01650250344000307

Parmar, P., Harkness, S., \& Super, C. M. (2008). Teacher or playmate? Asian immigrant and Euro-American parents' participation in their young children's daily activities. Social Behavior and Personality: An International Journal, 36(2), 163-176. http://dx.doi.org/10.2224/sbp.2008.36.2.163

Pierce, S., Alfonso, E., \& Garison, M. E. B. (1998). Examining proximal processes in young children's home environments: A preliminary report. Family \& Consumer Sciences Research Journal, 27(1), 3-34. http://dx.doi.org/10.1177/1077727X980271001

Rogoff, B. (1990). Apprenticeship in thinking: Cognitive development in social context. New York: Oxford University Press.

Rogoff, B. (2003). The cultural nature of human development. NY: Oxford University Press.

Rogoff, B., Mistry, J., Göncü, A., \& Mosier, C. (1993). Guided participation in cultural activity by toddlers and caregivers. Monographs of the Society for Research in Child Development, 58(8), 1-174. http://dx.doi.org/10.2307/1166109

Rogoff, B., Mosier, C., Mistry, J., \& Göncü, A. (1998). Toddlers' guided participation with their caregivers in cultural activity. In M. Woodhead, D. Faulkner, \& K. Littleton (Eds.), Cultural worlds of early childhood (pp. 225-249). London: Routledge.

Rosenthal, M. K., \& Roer-Strier, D. (2001). Cultural differences in mothers' developmental goals and ethno theories. International Journal of Psychology, 36(1), 20-31. http://dx.doi.org/10.1080/00207590042000029

Rummel, R. J. (1970). Applied factor analysis. Evanston, IL: Northwestern University Press.

Savage, S., \& Gauvain, M. (1998). Parental beliefs and children's everyday planning in European-American and Latino families. Journal of Applied Developmental Psychology, 19(3), 319-340. http://dx.doi.org/10.1016/S0193-3973(99)80043-4

Schwab, D. P. (1980). Construct validity in organization behaviour. In B. M. Staw, \& L. L. Cummings (Eds.), Research in organizational behaviour (pp. 3-43). Greenwich, CT: JAI Press.

Shrout, P. E., \& Fleiss, J. L. (1979). Intraclass correlations: Uses in assessing rater reliability. Psychological 
Bulletin, 86(2), 420-428. http://dx.doi.org/10.1037/0033-2909.86.2.420

Stevens, J. (1996). Applied multivariate statistics for the social sciences (3rd ed.). Mahwah, NJ: Lawrence Erlbaum.

Stevenson, H. W., \& Stigler, J. W. (1992). The learning gap. New York: Summit Books.

Streiner, D. L. (1994). Figuring out factors: the use and misuse of factor analysis. Canadian Journal of Psychiatry, 39, 135-140.

Suizzo, M. A. (2002). French parents' cultural models and childrearing beliefs. International Journal of Behavioral Development, 26(4), 297-307. http://dx.doi.org/10.1080/01650250143000175

Suizzo, M. A. (2004). French and American mothers' childrearing beliefs. Journal of Cross-Cultural Psycholgy, 35(5), 606-626. http://dx.doi.org/10.1177/0022022104268391

Super, C. M., \& Harkness, S. (1986). The developmental niche: A conceptualization at the interface of child and culture. International Journal of Behavioral Development, 9(4), 545-569.

Tabachnick, B. G., \& Fidell, L. S. (2001). Using multivariate statistics. New York: Harper \& Row.

Tamis-LeMonda, C. S., Wang, S., Koutsouvanou, E., \& Albright, M. (2002). Childrearing values in Greece, Taiwan, and the United States. Parenting: Science and Practice, 2(3), 185-208. http://dx.doi.org/10.1207/S15327922PAR0203_01

Taylor, R. L. (1994). Minority families and social change. In R. L. Taylor (Ed.), Minority families in the United States: A multicultural perspective (pp. 204-248). Englewood Cliffs, NJ: Prentice Hall.

Tsoukalas, K. (1977). Dependency and reproduction. The social role of the educational mechanisms in Greece (1830-1922). Athens: Themelio. [in Greek]

Tudge, J. R. H., Doucet, F., Odero, D., Sperb, T., Piccinini, C., \& Lopes, R. (2006). A window into different cultural worlds: Young children's everyday activities in the United States, Kenya, and Brazil. Child Development, 77(5), 1446-1469. http://dx.doi.org/10.1111/j.1467-8624.2006.00947.x

Tudge, J., Hayes, S., Doucet, F., Odero, D., Kulakova, N., Tammeveski, P., Meltsas, M., \& Lee, S. (2000). Parents' participation in cultural practices with their preschoolers: A cross-cultural study of everyday activities. Psicologia: Teoria e Pesquisa [Psychology: Theory and Research], 16(1), 1-11. http://dx.doi.org/10.1590/S0102-37722000000100002

Tudge, J., Hogan, D., Lee, S., Meltsas, M., Tammeveski, P., Kulakova, N., Snezhkova, I., \& Putnam, S. (1999). Cultural heterogeneity: Parental values and beliefs and their preschoolers' activities in the United States, South Korea, Russia, and Estonia. In A. Göncü (Ed.), Children's engagement in the world (pp. 62-96). New York: Cambridge University Press.

Tulviste, T., Mizera, L., De Geer, B., \& Tryggvason, M. T. (2007). Child-rearing goals in Estonian, Finnish and Swedish mothers. Scandinavian Journal of Psychology, 48, 487. http://dx.doi.org/10.1111/j.1467-9450.2007.00618.x

Van der Veer, R., \& van Ijendoorn, M. (1988). Early childhood attachment and later problem solving: a Vygotskian perspective. In J. Valsiner (Ed.), Child development within culturally structured environments. Parental cognition and adult-child interaction (Vol. 1, pp. 215-246). Norwood, NJ.: Alex Publishing Corporation.

Vega, W. A., Hough, R. L., \& Romero, A. (1983). Family life patterns in Mexican-Americans. In G. J. Powell, J. Yamamoto, A. Romero, \& A. Morales (Eds.), The psycho-social development of minority group children (pp. 194-215). New York: Brunuer-Mazel.

Vygotsky, L. S. (1978). Mind in Society: The development of higher psychological processes. Cambridge, MA: Cambridge University Press.

Vygotsky, L.S. (1934/1987). Thinking and speech. In R. W. Rieber, \& A. S. Carton (Eds.), The collected works of L.S. Vygotsky (Vol. 1. Problems of General Psychology). New York: Plenum Press.

Watkins, M. W. (2000). Monte Carlo PCA for parallel analysis [Computer Software]. State College, PA: Ed \& Psych Associates. 


\section{Note}

Note 1. The research reported in this paper was partly funded by the University of Athens, Greece, "Research project scheme KAPODISTRIAS".

\section{Copyrights}

Copyright for this article is retained by the author(s), with first publication rights granted to the journal.

This is an open-access article distributed under the terms and conditions of the Creative Commons Attribution license (http://creativecommons.org/licenses/by/3.0/). 